\title{
Türkiye’de Yeni Medya Düzeninin Oluşumunda Tasarruf Mevduatı Sigorta Fonu'nun Rolü
}

BORA ERDEM*

bora.erdem@marmara.edu.tr

Özet: Türkiye'de özellikle 1990sonrasında medya ve sermaye alanında önemli değişimler yaşandı. 1980'li yıllarda başlayan serbest piyasa ekonomisine geçiş sonrasinda ekonomi alanında yeni aktörler yer aldı. Aynı dönemde yaşanan siyasi ve ekonomik krizler, bünyesinde banka ve medya şirketleri barındiran holdinglerin batmasi sonucunu doğurdu. Batan bankalardaki mevduat sahiplerini koruma amact ile kurulan Tasarruf Mevduatı Sigorta Fonu (TMSF), bahse konu holdinglerin şirketlerine el koydu. Böylece önemli medya şirketleri de bir yönü ile iktidar kontrolüne geçmiş oldu. Bir müddet TMSF tarafindan yönetilen bu şirketler kamu ihale kanununa tabi olmayan ihalelerle iktidara yakın işadamlarına tahsisli olarak satıldi. Hükümete karşı oldukça yıpratıcı yayınlar yapabilen bu muhalif medya gruplarının (TMSF'nin odağında olduğu bu süreç sonrasinda) bir anda hükümeti destekler konuma geçmesi, iktidar lehine 'tarafl bir medya yapısı tasarımi' algisı oluşturdu. Elbette TMSF kurumsal anlamda bu sonucun oluşmasındaki tek unsur değildir. Çalışmanin sonunda görüleceği üzere, birçok devlet kurumu ve enstrümanı bu sonucun ortaya çıkmasında etkili olmuştur. Ancak burada konunun sinırlandırılması bakamından, TMSF’nin kuruluş ve işlevleri, medya TMSF ilişkisi ve bu süreçte TMSF marifetiyle sahiplik yapısı değiștirilen bazı medya şirketleri ele alınacaktır.

Anahtar kelimeler: TMSF, Medya, Demokrasi, Medya ekonomisi.

\section{Giriş}

Demokrasilerin ana unsurlarından olan medya halkın bilgi ve haber alma ihtiyac1nı karşılamak, kamuoyu oluşturarak toplumun beklenti ve taleplerini duyurmak ve kamu adına denetim görevi yapmak gibi önemli işlevleri haizdir. Bu nedenle, medyanın özgür bir şekilde görevlerini yapamadığı ortamlarda gelişmiş demokrasiden bahsetmek mümkün değildir. Zira demokrasinin sağlıklı şekilde işlemesi yurttaşların doğru bilgiye ulaşıp siyasi tercihlerini buna göre belirlemesiyle doğrudan ilgilidir. James Madison'un ifade ettiği gibi "Halkın bilgili olmadığı ya da bilgi alacak kaynaklara sahip olmadığı bir halk yönetimi olsa olsa bir komedinin ya da trajedinin, belki de ikisinin birden önsözü olabilir. Bilgi her zaman cehaleti yönetir; kendi kendisini

\footnotetext{
* Öğr. Gör., Marmara Üniversitesi, Adalet Meslek Yüksekokulu.
} 
yönetmek isteyen bir halkın da kendisini bilgiden gelen güçle donatması şarttır."

Amerikalı araştırmacı gazetecilere (muckraker) göre "Haber, bir yerlerde birilerinin basılı olarak görmek istemediğidir.” $\mathrm{Bu}$ tanımın büyük bir kısmını özellikle iktidarların görmek istemedikleri oluşturur. Onun için, iktidarların basın gücünü elde etmeye çalışmaları ve kendi politikalarını halka kabul ettirmede basını kullanma çabaları dünyanın hemen her yerinde görülür. Bu durum yönetimin niteliğine göre kimi yerde oldukça baskın şekilde yaşanır; kimi yerde de, hukukun ve denetim mekanizmalarının sağlıklı işlediği, medya sahiplik yapısının sorunsuz olarak düzenlendiği, medya mensuplarının basiretli ve erdemli duruş sergileyebildiği yerlerde bu baskı en aza indirgenerek yaşanır.

Türkiye'de sermaye-medya ilişkisindeki çarpıklıklar, iktidar-medya ilişkisinde olduğu gibi demokrasi ortamlarını tehdit eder boyutlara ulaşabilmektedir. Hatta bazen iktidar-sermaye ve medya, çıkar ilişkileriyle kısır bir döngü oluşturarak toplumu adeta nefes alamaz hale getirebilmektedir. Bu durumda sadece iktidarın istediği konular ülkede gündem olmakta, istemediği hususlar ise kamu yararına muhalif bir şekilde gündeme gelmemektedir. Uluslararası basın kuruluşları raporlarında, Avrupa İnsan Hakları Mahkemesi (AİHM) ise son dönemde aldığı kararlarla Türkiye'de ifade özgürlüğü, basın özgürlüğü konularında dramatik irtifa kaybı tespit etmektedirler. ${ }^{3}$ AİHM, özellikle Türkiye ile ilgili almış olduğu Kentbank kararında ${ }^{4}$ Türkiye'yi önemli meblağda tazminata mahkûm ederek TMSF'nin keyfi uygulamalarına uluslararası bağlamda dikkat çekmiştir.

Basın, günümüzde önemli bir sektör haline gelmiştir. Özellikle yazılı basın alanında ulusal ölçekte yayıncllı yapabilmek önemli büyüklükte yatırımlar gerektirmektedir. Bu yüzden ulusal ölçekteki basın piyasası rekabetçi sayısı açısından çeşitliliği çok yüksek olmayan bir piyasadır. Ancak çok büyük sermaye grupları basın alanında (ulusal ölçekli) yatırımlar yapabilmekte, hatta çoğu zaman bu medya şirketleri zarar etmekte; bu zararlar holding çatısı altındaki yüksek kârlı diğer şirketler tarafından sübvanse edilmektedir. Gazeteci Doğan Akın’n tarifiyle "medya patronları başka alanlardaki yatırımlarının bekası için medyadaki zararları satın almakta ve satın almaların ardından ilan ettikleri "zarar"la var olan medya düzeninin bekasını sağlamaktadırlar." Ayrıca medya kuruluşlarının en önemli gelir kaynağı olan reklam pastasının darlığı, yatırım ve işletme maliyetlerinin çok yüksek olması, yatırımcılar açısından medyayı itici kılmaktadır.

$\mathrm{Bu}$ daralmış pazar yapısının oluşmasında çapraz birleşmeleri engelleyen mevzuat eksikliği ile birlikte medya gruplarının başka alanlara yatırım yapmaları etkili ol-

1 James Madison, The Writings of James Madison, ed., Gaillard Hunt (Chicago: University of Chicago Press, 2000), s. 103.

2 John Keane, Medya ve Demokrasi, çev., Haluk Şahin (İstanbul: Ayrıntı Yayınları, 2010), s. 134.

3 BBC Türkçe, “Türkiye basın özgürlüğünde 180 ülke arasında 154. sırada”, 12 Şubat 2014. http://www.bbc.com/ turkce/haberler/2014/02/140212_rsf_turkiye. Erişim: 15.04.2015.

4 AIHM, "Süzer ve Eksen Holding v. Türkiye Kararı", Karar No: 6334/05, Tarih: 23.10.2012.

5 Doğan Akın, "Medya Patronları, Bırakın Biraz da Başkaları Ölsün!”, T24, 18 Haziran 2012. http://t24.com.tr/ yazi/ medya-patronlari-birakin-biraz-da-baskalari-olsun. Erişim: 10.07.2012. 
muştur. Bu yüzden, çoğunlukla devletle iş yapan ve farklı alanlarda yatırımları olan büyük gruplar, medya şirketleri nedeniyle maruz kalacakları zararları göze alarak bu alanda yatırım yapmaktadırlar. Medya açısından değerlendirildiğinde, iktidara ya da diğer şirketlere karşı bir baskı unsuru şeklinde kullanılan yayın organları oluşmaktadır. İktidar açısından ele alındığında ise hukuki-idari araçları kullanmak suretiyle bu gruplara baskı yapılmakta, sonuçta kamunun zarar gördüğü, demokrasinin yara aldığı süreçler yaşanmaktadır.

Gelişmekte olan ülkeler sınıfında yer alan Türkiye, birçok dönemde medya ve demokrasi açısından iyi bir sınav verememiştir. Demokratik ölçüler ülkede yeterince yerleşmemiş, olgun bir vatandaşlık bilincine ve demokrasi kültürüne ulaşılamamıştır. Vatandaşlar ve medya tarafından yeterince denetlenemeyen iktidar, milletten aldığ 1 yetkiyi kullanırken kamu yararından uzak hareket edebilmiştir; bu çerçevede teftiş müesseselerini, genel ve yerel bürokrasiyi, TMSF, Bankacılık Düzenleme ve Denetleme Kurumu (BDDK), Basın İlan Kurumu (BİK), Basın Enformasyon Kurumu (BEK), Anadolu Ajansı (AA) ve Radyo ve Televizyon Üst Kurulu (RTÜK) gibi birçok devlet kurum ve enstrümanını medya gruplarına karşı bir baskı unsuru olarak kullanmaktan çekinmemiştir.

Sermaye-iktidar ve medya ilişkisinin çarpıklığı özellikle 28 Şubat 1997 sürecinde 6 ve bunu izleyen dönemde hayli derin şekilde yaşanmıştır. Bu dönemde banka sahibi olmuş medya gruplarının kendi bankalarından usulsüz kredi kullanımları ya da bankalara olan yüklü borçlarından dolayı mevzuat gereği tüm varlıklarıyla birlikte devlete (TMSF) geçmesiyle sonuçlanan süreçler yaşanmıştır. Bu dönemde birçok önemli medya grubu, TMSF yoluyla iktidar kontrolüne geçmiş ve bir müddet sonra ihale yoluyla hükümete yakın kişi ya da firmalara devrolmuştur.

TMSF, mevzuatı gereği söz konusu medya kuruluşlarına el koymuş, bu şirketleri belli bir dönem kendi atadığı yetkililerle yönetmiş, hatta bazı yayın organlarını yıllarca uhdesinde tutmak suretiyle adeta iktidar yayıncılığı yapmış ve bu tartışmalı süreç sonunda bu şirketler yine tartışmalı ihalelerle el değiştirmiştir. Bu süreçler, Türkiyedeki mevcut medya ortamının oluşmasında belirleyici rol oynamıştır. Uluslararası düzlemde de Avrupa İnsan Hakları Mahkemesi ve uluslararası basın kuruluşları son dönemde aldıkları kararlarla, Türkiye’nin ifade ve basın özgürlüğü konularında geri gittiğini tespit etmişlerdir.

\section{Mevduat Sitemi ve Türkiye'de TMSF’nin Kuruluşu}

Mevduat sigortası, Amerikalı finans profesörü Mark Flannery’e göre, bankaların ödeme gücünü yitirmesinden doğabilecek zarar riskini banka mudilerinin üzerin-

628 Şubat süreci, 28 Şubat 1997’de yapılan Milli Güvenlik Kurulu toplantısı sonucu açıklanan kararlarla başlayan ve irticayla mücadele adı altında, ordu ve bürokrasi merkezli olağandışı bir süreçtir. Alınan kararlar ve bu kararların uygulanmasında, Türkiye’de siyasi, idari, hukuki ve toplumsal alanlarda olağandışı yaptırımlarla değişimlere neden olunmuştur. Bazı yazarlar tarafından bu olağandışı duruma, post-modern darbe olarak nitelendirilmiştir. Detaylı bilgi için bkz: Erkan Yüksel, “28 Şubat’ın Anlamı...”, Özgür Gazeteciler Platformu, 28 Şubat 2011. http://dorduncukuvvet.com/erkanyuksel/3093-28-subatin-anlami.html, Erişim: 01.03.2015; İsmet Berkan, "Postmodern Darbe mi?", Radikal, 26 Şubat 2003. http://www.radikal.com.tr/yazarlar/ismet_berkan/ postmodern_darbe_mi-667916, Erişim: 01.02.2015. 
den alarak, bu tür riskleri hükümet ya da bu amaçla kurulmuş özel kurumlardan oluşan konsorsiyuma transfer eden bir sistemdir7. Bankacilık sektörünün istikrarsızlığı, ödeme sistemindeki yetersizlikler ve tasarruf oranlarındaki azalış, reel sektör ve bankalar arasındaki finansal aracılık sürecinin bozulmasına sebep olabilmektedir. Dünyanın hemen her yerinde bankalar sıkı denetim ve kontrol altında tutulsa da ülke tecrübeleri göstermiştir ki, mevduat sahipleri, bankalar ödeme güçlükleriyle karşılaştığında koruyucu sigorta yapılarına ihtiyaç duymaktadırlar. Bankaların yaşayabileceği kriz ve batma durumlarında bankalara hücumlarının engellenmesi ve tasarruf sahiplerini korumak, mevduat sigortasının kurulmasının temel nedenidir. ${ }^{8}$

Mevduat sigorta sistemi, ilk kez 1829 yllında ABD’nin New York eyaletindeki ticaret bankalarının borç senedi ihraçlarını ve mevduatını güvence altına almak amacıyla kurulmuştur. Daha sonra ABD’nin çeşitli eyaletlerinde benzeri sistemle kurulmuş ve sistem 1933 yllinda kurulan Federal Deposit Insurance Corporation (FDIC) ile kurumsal boyut kazanmıştır. Sistemin ulusal anlamda ilk uygulamasına 1924 yılında Çekoslovakyada rastlanmaktadır. 1970'li ylllardan sonra mevduat sigorta sistemi tüm dünyada yaygınlaşmış, 1994 yılından itibaren Avrupa Birliği’nde bankacılık düzenlemelerinde mevduat sigorta sistemleri standardı getirilmiştir. Bu sistem ülkelerin yerel şartlarına göre değişiklik gösterebilmektedir. Sisteme girişin zorunlu olup olmaması, hangi tür ve miktarda mevduatların güvence altına alınacağı, kapsama alınan mevduat türünün ne kadarının sigortalanacağı, sistemin yürütülmesinde devletin ya da özel kuruluşların yetkili olup olmaması, fonlamanın nasıl yapılacağı ve prim matrahının belirlenme usulleri ülkelerin yerel dinamik ve değerlendirmelerine bağlı olarak değişiklik göstermektedir. ${ }^{9}$

Türkiye'de 1983 yllında tasarruf sahiplerini koruma amaciyla kurulan TMSF hakkında, kurumun kendi web sayfasında yer alan bilgiler özetle şu şekildedir: TMSF, temelde tasarruf ve mevduat sahiplerini bankaların batması durumunda koruma amacıyla kurulmuş olan özellikle batan bankaların alacaklarını kamu adına takip ederek koruma görevi olan ülkemizdeki üst kurullardan birisidir. Fon Yönetim Kurulu Bakanlar Kurulu tarafindan atanır. Tasarruf Mevduatı Sigorta Fonu, 5411 sayılı Kanun ve ilgili diğer mevzuat ile verilen yetkiler çerçevesinde tasarruf sahiplerinin hak ve menfaatlerinin korunması amaciyla, mevduatın ve katılım fonlarının sigorta edilmesi, Fon bankalarının yönetilmesi, mali bünyelerinin güçlendirilmesi, yeniden yapılandırılması, devri, birleştirilmesi, satışı, tasfiyesi, Fon alacaklarının takip ve tahsili işlemlerinin yürütülmesi ve sonuçlandırılması, Fon varlık ve kaynaklarının idare edilmesi ve kanunla verilen diğer görevlerin ifası için kurulmuş olup kamu tüzel kişiliğini haiz, idarî ve mali özerkliğe sahip bir kuruluştur.

Mevduat sigortası sistemi mevduatın korunmasına ilişkin günümüze kadar oluşturulan kurumların en gelişmişidir. Sistem mevduat sahibi, mevduatı kabul eden

7 Mark J. Flannery, “Deposit Insurance”, The New Palgrave Dictionary of Money and Finance, (London: The Macmillan Press, 1994), s. 23.

8 Ercan Balaban ve Hüseyin Çilli, "A Proposal For A Deposit Insurance System In Turkey“, The ISE Review. 1/2 (1997): s. 2.

9 Coşkun Küçüközmen, “Mevduat Sigortası”, İşletme İktisat ve Finans Dergisi. 11/22 (1996): s. 45-53. 
banka ve mevduatı sigorta altına alan kurum arasında işlemektedir. Mevzuatı gereği yaptırım gücü bulunmaktadır. Sigortayı yapan kurum işlem karşılığında belirli bir tutarda prim tahsil eder. Kurum, mevduatın yatırıldığı bankanın ilgili mevzuatta yazılı olan hükümler çerçevesinde mevduat sahibinin mevduatını geri ödeyememesi durumunda devreye girer. Mevduat sahibi ya da sahiplerine sigorta kapsamına aldığ 1 tutar kadar mevduatı öder. Ödediği tutarları geri almak üzere de ödeme güçlügüune düşen banka hakkında yasal süreci başlatır. ${ }^{10}$

Mevduat sigorta sistemi, dünyada güçlü bir yasal altyapıyla desteklenir. Böylece, banka sahipleri ve yöneticilerinin sorumluluklarını açık bir şekilde görebilmesi bankaların iç yönetiminin geliştirilmesine katkıda bulunur. Uluslararası standartlardaki muhasebe ve raporlama sistemleri gerçekçi bir kredi değerlemesi sağlar ve piyasa disiplinini güçlendirir. Ayrıca banka bilgilerinin topluma açıklanmasının piyasa disiplini üzerinde olumlu etki yapacağı öngörülür. Merkez Bankası ve denetim otoritesi ile yakın ilişki içinde olması da mevduat sigorta sisteminin başarısında etkili unsurlar arasinda sayılır. ${ }^{11}$

Denetim otoritesiyle yakın ilişkide olması, sistemin denetlenemeyen bir yapı haline getirilmesi anlamina gelmemektedir. Tasarruf Mevduatı Sigorta Fonu (TMSF), 22 Temmuz 1983 tarih ve 70 sayılı Bankacılık Hakkında Kanun Hükmünde Kararname ile bankalardaki tasarruf mevduatını sigorta etmek amacıyla tüzel kişiliği haiz olarak kurulmuştur. TMSF'yi, ilgili Bakanlıkça hazırlanacak bir yönetmelik dâhilinde idare ve temsil etme görevi Türkiye Cumhuriyet Merkez Bankası'na (TCMB) verilmiştir. TMSF’nin Maliye Bakanlı̆̆ı’nca hazırlanan ilk yönetmeliği 25 Ekim 1983 tarihinde yayımlanmıştır. Türkiye'de 4389 sayılı Bankacılık Kanununda bankalardaki tasarruf mevduatının kamu tüzelkişiliğini haiz “Tasarruf Mevduatı Sigorta Fonu” tarafından sigorta edileceği belirtilmiştir. Fon, tasarruf mevduatının sigorta edilmesi, temettü hariç ortaklık hakları ile yönetim ve denetimi kendisine geçen bankaların mali bünyelerinin güçlendirilmesi, yeniden yapılandırılması, belli bir süre işletilmesi, sonrasında ve bahsi geçen mevzuat ile kendisine verilen diğer işleri de yapmakla görevli ve yetkilidir. Görüldüğü üzere, TMSF'nin kuruluş amacı bakımından sadece tasarrufları sigorta etmekten öte zor duruma düşen bankaların yapılarını güçlendirip makul bir tasfiye ortamı oluşturmayı da hedeflediği görülmektedir. ${ }^{12}$

Fon görevini yaparken bağımsızdır. Fon'un kararları yerindelik denetimine tâbi tutulamaz. Hiçbir organ, makam, merci veya kişi, Fon Kurulu’nun kararlarını etkilemek amacıyla emir ve talimat veremez. Fon, 3346 sayılı Kamu İktisadi Teşebbüsleri ile Fonların Türkiye Büyük Millet Meclisince Denetlenmesinin Düzenlenmesi Hakkında Kanun, 2886 sayılı Devlet İhale Kanunu ile 4734 sayılı Kamu İhale Kanunu (KİK) hükümlerine tabi değildir. Fonun malları Devlet malı hükmündedir. Fonun mal, hak ve alacakları haczedilemez ve rehin edilemez." ${ }^{13}$ Mevzuatında var olmasına rağmen,

10 TMSF, “TMSF Tarihçesi”, http://www.tmsf.org.tr/tarihce.tr, Erişim: 07.04.2015.

11 Gillian Garcia, “Deposit Insurance and Crisis Management”, IMF Working Paper, 99/54 (1999): s. 14.

12 Müge Ayzit, "Dünyada ve Türkiye’de Mevduat Sigorta Sistemi Uygulamaları” (Uzmanlık Tezi, TCMB, 2004), s. 45 .

13 TMSF, “TMSF İdari ve Hukuki Yapı”, http://www.tmsf.org.tr/idari.hukuki.tr. Erişim: 07.04.2015. 
Fon'un ne ölçüde özerk olduğu konusu tartışmalıdır. Ayrıca uhdesine geçen şirketleri bir müddet sonra "kamu ihale kanununa tabi olmadan" ihale edebilmesi hayli tartışmalı bir husustur.

TMSF sigortacılık faaliyetleri yoluyla Bankacılık Kanunu ve ilgili diğer mevzuat çerçevesinde çeşitli gelirler elde etmekte ve bu gelirleri değerlendirmektedir. TMSF'nin gelirlerindeki artış ve elde ettiği varlıkların efektif bir şekilde kullanılması geleceğe dönük olarak sistemin rahatlamasına ve bankacilık sistemine olan güvenin artmasina yöneliktir. Bunlara ilave olarak, TMSF'nin borçlanma ve avans alma yetkisi de bulunmaktadır. Bankalar kanununa göre TMSF Hazine Müsteşarlığından izin almak kaydıyla borçlanabileceği gibi, ihtiyaç hâsıl olduğunda TMSF’ye ikrazen verilmek üzere Hazine Müsteşarlığınca özel tertip devlet iç borçlanma senedi de ihraç edebilmektedir. Bahsi geçen devlet iç borçlanma senetlerinin faiz oranları ve geri ödeme şartları da dâhil olmak üzere tabi olacağı usul ve esaslar Hazine Müsteşarlığı ile TMSF tarafından müştereken belirlenmektedir. ${ }^{14}$

TMSF ayrıca BDDK’nın onayı ile bankaların bir önceki yıl ödedikleri prim tutarı toplamina kadar bankalardan avans alabilmektedir. ${ }^{15} \mathrm{Bu}$ yönüyle de TMSF'nin yasalarla oldukça ayrıcalıklı hale getirilmiş bir kurum olduğu dikkati çekmektedir. TMSF, özellikle serbest piyasa ekonomilerindeki en önemli ve hassas piyasa aktörlerinden olan bankalarla ilgili yapısından ötürü bu şekilde kurgulanmış bir kurumdur.

Genel olarak, TMSF’nin özerk yapısı, kamu ihale kanununa tabi olmaması, gerektiğinde Merkez Bankasından ya da diğer bankalardan borç alabilmesi ve Fon $\mathrm{Ku}$ rulu'nun hiçbir merci ve kişinin emrinde olmaması (mevzuata uyulması halinde), Fon'un kuruluş kanunu ve yapısından gelen önemli ayrıcalıklarıdır. Ancak kamuoyu algısını yöneten ve desteğini arkasına alan iktidarlar ile halkın menfaatini koruma amaçı kurulmuş bu imtiyazlı kurum arasındaki ilişkiler mevzuatta belirtildiğinin dişında seyredebilmektedir. TMSF’nin uhdesine geçen medya şirketlerinin yönetimini istedikleri kişilere devrederek iktidarı hemen hemen hiç eleştirmeyen yayın organları haline getirip işletmesi, en önemli tartışma konularındandır. Takip ettikleri

145411 sayılı Bankalar Kanunu’nun "Fonun Borçlanma ve Avans Yetkisi” başlığı altındaki 131. maddesi; "Fon, Hazine Müsteşarlığından izin almak kaydıyla borçlanabileceği gibi ihtiyaç hasıl olduğunda Fona ikrazen verilmek üzere Hazine Müsteşarlığı’nca özel tertip Devlet iç borçlanma senedi ihraç edilebilir. Özel tertip Devlet iç borçlanma senetlerinin faiz oranları ve geri ödeme şartları da dahil olmak üzere tâbi olacağı usûl ve esaslar Hazine Müsteşarlığı ile Fon tarafından müştereken belirlenir. Malî yıl bütçe kanunlarında yer alan borçlanma ile ilgili hükümler ile 4749 sayılı Kamu Finansmanı ve Borç Yönetiminin Düzenlenmesi Hakkında Kanunun 5. ve 6. maddeleri hükümleri bu senetler için de geçerlidir.

Fon, Kurum görüşü alınmak suretiyle Fon Kurulu kararı ile bankalardan ileride doğacak prim yükümlülüklerine mahsuben bir önceki yılda ödedikleri sigorta primi toplamına kadar avans alabilir. Avans kullanımına ilişkin kararlarda uygulanacak faiz oranının belirtilmesi zorunludur.

Olağanüstü hallerde, Fon kaynaklarının ihtiyacı karşılamaması durumunda Fonun talebi üzerine Merkez Bankasınca Fona avans verilebilir. Alınan avansın vadesi, tutarı, geri ödeme şekil ve şartları ile uygulanacak faiz oranı ve diğer hususlar Fonun görüşü alınarak Merkez Bankasınca belirlenir” şeklindedir.

15 02/09/2006 tarih ve 26277 sayılı Resmi Gazete yayımlanan, “Tasarruf Mevduatı Sigorta Fonunun Kaynakları İle Kaynakların Kullanımına Dair Yönetmelik” 5/1-b maddesi; “(1) Kanunun 131 inci maddesi hükümlerine göre, b) Fon, Bankacılık Düzenleme ve Denetleme Kurumu görüşü alınmak suretiyle Kurul kararı ile bankalardan ileride doğacak prim yükümlülüklerine mahsuben bir önceki yılda ödedikleri sigorta primi toplamına kadar avans alabilir" şeklindedir. 
yönetim tarzı ve yayın politikaları dolayısıyla olağan bir şekilde etkisi kırılan, satışları düşen veya reytingi azalan, dolayısıyla piyasa değeri düşen yayın organlarını kamu ihale kanununa tabi olmadan değerlerinin çok altında rakamlarla satışa sunmaları, kurumun eleştirilen bir diğer yönüdür.

Tasarruf mevduatı sigorta sistemi, örnekleri dünyada var olan ve tasarruf sahiplerini koruma amaçlı kurulan, kurumsal özelliklerinden dolayı ciddi imtiyazlara sahip bir yapıdır. Ancak bu ayrıcalıklar, iktidarların yönetim politikalarındaki keyfiliklerle çok olumsuz sonuçlar doğurabilmektedir. Özellikle denetim organlarının etkili çalışamadığı ortamlarda, siyasal, ekonomik ve sosyal sonuçları hayli ağır yaşanmaktadır.

\section{TMSF-Medya İlişkisi}

TMSF’nin temel kuruluş felsefesi ve amaçları bakımından medya ile doğrudan herhangi bir ilişkisi bulunmamaktadır. Ancak ulusal ölçekli medya yatırımları çok büyük mali imkânları gerektirdiğinden ve medyanın kendi imkânları ve yatırımlarıyla varlığını sürdürmesi güç olduğundan, medya şirketleri genellikle, büyük holding ve içinde bankaların da bulunduğu gruplar içerisinde yer almaktadır. Bu grup ya da holdingler, genel bir ekonomik kriz ya da kendi yaşadıkları ekonomik sıkıntı durumlarında bankacılık faaliyetleri nedeniyle TMSF’nin müdahalesine maruz kalabilmekteler. Bu duruma bağlı olarak da grubun bünyesinde yer alan diğer şirketlerin yanında medya şirketleri de TMSF uhdesine geçebilmektedir.

Türkiye'de basın 1960'lardan itibaren endüstrileşmeye başlamış, özellikle 1980 sonrasında basın üzerinde ekonomik etkenler daha belirleyici olmuştur. Dünyayla benzer şekilde Türkiye`yi de etkileyen neoliberal ekonomi anlayışı ve deregülasyon politikaları, gazete ve dergi yayıncılarının holdingleşme yönünde adımlar atmasına ve başka sektörlerde faaliyet gösteren sermaye sahiplerinin bu alana yönelmesine neden olmuştur. Bu holdingleşme ve büyüme eğilimi, 1990 sonrasında özel radyo ve televizyon yayıncılığının başlamasıyla daha da hızlanmıştır. Mevcut imkanlardan faydalanarak agresif büyüme stratejileriyle güçlerini arttıran, promosyon ağırlıklı rekabet mücadeleleriyle varlıklarını sürdüren medya grupları 2001 krizinden olumsuz etkilenmiştir. Krizden özellikle finans sektöründe yatırımı bulunan medya grupları daha ağır etkilenmiş, bazıları piyasadan tamamen silinmiş, bazıları ise TMSF'ye devrolmuştur. TMSF 2002'den itibaren elindeki medya şirketlerini belli süreler işlettikten sonra satışa çıkarmaya başlamıştır. Ekonomideki olumlu gelişmelere bağlı olarak özellikle 2005 yılından itibaren yatırım açısından medyaya ilgi artmıştır. ${ }^{16}$

TMSF sonuçta iktidarın atadığı bürokratlarla yönetilen bir yapı olduğundan, el konulan şirketlere atanan kayyum ve idareciler de genel itibariyle iktidara yakın yöneticiler olmuştur. Bahse konu şirketler arasında, seramik, cam, maden ve enerji gibi çok farklı sektörlerde faaliyet gösteren şirketler olmasına karşın, kamuoyunun ilgi odağında daima medya şirketleri yer almıştır.

Hemen her dönemde, iktidarlar kendi politikalarını rahat uygulamak ve muhalefetin

16 Ceren Sözeri ve Zeynep Güney, Türkiyede Medyanın Ekonomi Politiği: Sektör Analizi (İstanbul: TESEV Yayınlar1, 2011), s. 15. 
sesini kısmak amacıyla medyayı bir şekilde kendi tarafına çekme çabasına girmiştir. Yaşanan siyasi ve ekonomik çalkantılar sonucunda, TMSF’nin bu holdinglere el koyması iktidarların iştahını daha da kabartmıştır; el konulan medya organlarını istedikleri gibi yönetme, yayınlarını belirleme ve adeta hükümet yayını haline getirme imkânı bu yolla kendilerine sunulmuştur.

Ana akım medyanın büyük bir çoğunluğu, en fazla okuru, izleyicisi olan gazete ve televizyonlar bu yolla önce TMSF elinde genellikle uzunca süreler muhalefetsiz ve hükümet yanlısı yayın mecraları haline gelmiş; daha sonra da iktidara yakın iş adamlarına Kamu İhale Kanunu'na tabi olmayan satış yöntemleriyle devredilerek medyada adeta yeni bir düzenleme gerçekleştirilmiştir.

Medya yapısının el değiştirme sürecinde TMSF’nin bir manivela gibi kullanılması hususuna 2014 yılında yapılan medya araştırmaları kongresinde işaret edilmiştir. “TMSF’nin el koyduğu şirketlerin, iktidara yakın hatta iktidarla organik bağı olan kişi ya da kuruluşlara kamu kredileri yoluyla devredilmesine, ihale sonucu beğenilmediği takdirde 'rekabetin oluşmadığı' gerekçesiyle firmaların ihaleden bir şekilde uzaklaştırıldıklarına" dikkat çekilmiştir. ${ }^{17}$

2001 krizi sonrasında borçlarını ödeyemez hale gelen bankalara devlet TMSF marifetiyle el koydu. Türkiye'de siyaset ve ekonomiyi derinden etkileyen bu krizde 25 banka batmıştır. Dönemin TMSF Başkanı Ahmet Ertürk’ün ifadesine göre ${ }^{18}$ bu bankaların on tanesi aynı zamanda medya sahibi (televizyonu, gazetesi veya ikisi birden) olan bankalardır. ${ }^{19}$

2001 krizi öncesinde, 1990’larda medya pazarının deregülasyonu sonucu medya sahipleriyle devlet arasında patronaj ilişkisi gündeme gelmiş, medya sahipleri başka alanlardaki yatırımlarından daha fazla kâr etmek için politikacılara sahip oldukları medya aracılığıyla baskı uygulamaya başlamıştır. ${ }^{20}$ Özellikle koalisyon hükümetleri dönemlerinde uyguladıkları denge politikalarıyla iktidarlardan istediklerini almış; ekonomik olarak güç kazanmışlardır.

Gazeteci-ekonomist Cemil Ertem bu dönemi medya ve bankacılık sektörü bağlamında şöyle dile getirmiştir:

“1989 tarihi Türkiyede mali serbestleşmenin miladıdır. Bu tarihte 32 sayılı kararname ile Türk Parasını Koruma Kanunu rafa kaldırılarak yabancı fon akışı ve girişi serbestleştirilmiştir. Bu tarihten sonra Türkiye'de iki şeyin sahibi olmak önemli sayılmıştır: Birincisi banka sahibi olmak, ikincisi bir TV ve gazete sahibi olmak. Yani dışarıdan gelen milyarlarca doları yönlendirebil-

17 Ceren Saran, "Medyada Mülkiyet İlişkileri: AKP Döneminde Medya Sahipliğinde Yaşanan Değişimler”, I. Uluslararası İletişim Bilimi ve Medya Araştırmaları Kongresi Türkiye Bildiri Kitabı - I, (Kocaeli: Volga Yayıncılık, 2014), s. 369.

18 TBMM 28 Şubat Araştırma Komisyonu, “16.10.2012 tarihli oturum tutanağı”, https://www.tbmm.gov.tr/ arastirma_komisyonlari/darbe_muhtira/docs/tutanak_son/28_subat_alt_komisyonu/28_subat_alt_ komisyonu/16.10.2012/Ahmet\%20Ert\%C3\%BCrk-16.10.2012.pdf. Erişim: 07.04.2015.

19 Ceren Sözeri, Türkiye’de Medya-İktidar İlişkileri (İstanbul Enstitüsü Yayınları, 2015), s. 11.

20 Clayton Christensen, "Concentration of ownership, the fall of unions and government Legislation", Global Media and Communication, 3/2 (2007): s. 185. 
mek için medyanın dokunulmazlığını, gücünü arkasına almak. İşte doksanlı yıllarda Türk hâkim sermayesi ve ona yetişmeye çalışan sermaye grupları bu iki amaç için birbirleriyle yarışır oldular. 1994 krizini sahip olduğu bankalar sayesinde atlatan bu yeni sermaye grubu, 2001 krizinin bir finans ve banka krizi olarak başlamasıyla çok yüksek "açık pozisyonlarla" krize yakalandı. Kısa süre sonra 2001 krizinin sadece bir banka ve finans krizi olmadığı, çok yönlü ve çok derin bir yeniden yapılanma anaforu olduğu anlaşılmıştır. 1989'dan beri usulsüz banka kredileriyle büyüyen ve artık uluslararası tekelci sermayeyi bile tehdit eder duruma gelen bu yeni zengin grubunun, bu anaforda tasfiye edilmesiyle bankacılık sisteminin küreselleşerek sağlamlaşmas1 ve sermayenin ilk sahiplerine geri dönmesi hedeflenmiştir. Türkiye’de bu yolu, alışılmışın dışında bir devlet kurumu olan TMSF açmıştır." ${ }^{21}$

Türkiye'de medyadan para kazanan şirket yok denecek kadar azdır. Medya normal bir yatırımcı için cazip bir yatırım alanı değildir. Fakat büyük sermaye grupları, bünyesinde bulunan diğer şirketlerini "korumak, diğer alanlarda yeni ihaleler almak, rakiplerine karşı üstünlük ve güç elde etmek” gibi sebeplerle çok büyük orandaki zararlara da katlanarak medya sektöründe bulunmayı sürdürmektedirler.

Türkiye'de 2001 krizinden en fazla etkilenen alanlar medya ve finans sektörü olmuştur. Krizle birlikte, finans sektöründe faaliyet gösteren şirketlerin medya kuruluşları ya pazardan silinmiş ya da finans kuruluşlarıyla birlikte TMSF’ye (dolayısıyla devlete) devrolmuştur. Bu durumdan en fazla etkilenen de Etibank'a el konulmasiyla medya alanındaki faaliyetlerinin bir kısmı durma noktasına gelen, Yeni Asır ve Sabah gazeteleri ile ATV televizyonunun sahibi Dinç Bilgin’e ait Bilgin Grubu olmuştur. Yine aynı dönemde TMSF tarafından Kamuran Çörtük'ün Bayındır Bank’na el konulduğunda BRT TV, Erol Aksoy'un sahibi olduğu İktisat Bankası'na el konulunca Cine 5, Mustafa Süzer'e ait Kent Bank'a el konulunca Kent TV, Ceylan Grubu'nun Bank Kapital'inin fona devrolmasıyla CTV, TMSF uhdesine geçerek piyasadan silinmişler; bu durum bir çok banka çalışanı ve gazetecinin işsiz kalmasına sebep olmuştur ${ }^{22}$. Aynı dönemde Karamehmet Grubu medyada daha fazla yatırım yaparak pozisyonunu güçlendirmeye çalışırken el konulan İhlas Finans sebebiyle Türkiye Gazetesi ve TGRT de zor ve sarsıntılı bir döneme girmiştir. ${ }^{23}$

Türkiye Gazeteciler Sendikası (TGS) verilerine göre 3900, Çağdaş Gazeteciler Derneği'nin tespitine göre 4815 gazetecinin işsiz kaldığı bu krizde, reklam gelirleri de yaklaşık \%50 düşüşle bir milyar dolardan 500 milyon dolara inmiştir. ${ }^{24}$ Bu dönem finans sektörüyle içli dışlı hale gelen medya sektörüne çok büyük bir darbenin vurulduğu, dolayısıyla Türk Medyası için de bir kriz dönemi olmuştur. Bu krizde diğer şirketlere nazaran pek de etkilenmeyen Aydın Doğan’a ait Doğan Grubu, Bilgin

21 Cemil Ertem, “Medya, Finans ve bir buzkıran olarak TMSF”, Taraf, 10.06.2008.

22 Ayhan Gençler, "2001 Ekonomik Krizinin Bankacılık Sektöründeki İstihdama Etkisi”, Sosyal Siyaset Konferanslar1, 50 (2005), s. 357-359.

23 Mustafa Sönmez, "Dünden Bugüne Türkiye’de Medyanın Ekonomi Politiği”, haz. Esra Arsan ve Savaş Çoban. Medya ve İktidar (İstanbul: Evrensel Basım Yayın, 2014), s. 95.

24 Atilla Özsever, Tekelci Medya Örgütsüz Gazeteci, (Ankara: İmge Yayınevi,2004), s. 186. 
Grubu'na ait medya kuruluşlarına talip olmuş fakat bu girişiminde başarılı olamamıştır. Dinç Bilgin, TMSF ile anlaşarak bu kuruluşları Turgay Ciner'e ait Park Grubu'na vermiştir. Ancak 2007 yılında Dinç Bilgin'in TMSF'ye başvurmasıyla TMSF, muvazaalı işlem gerekçesiyle bahse konu şirketlere el koymuştur. 2007 yılında da bu grup iktidara yakınlığıyla bilinen Çalık Grubuna iki kamu bankasından alınan çok iyi şartlardaki kredi desteğiyle satılmıştır. Aynı grup yine 2013 yılında basında çok tartışılan bir şekil ve usulle Kalyon AŞ’ye ait Zirve A.Ş.ye Rekabet Kurulu onayıyla satılmıştır. İktidara yakın müteahhitlerden toplanan paralarla oluşturulan bir para havuzuyla bu alımın gerçekleştiği haberleri basına yansımış ve bu durum uzun süre kamuoyunda tartışılmıştır. ${ }^{25}$

Adalet ve Kalkınma Partisi (AKP), 2002 yılında iktidara geldiğinde başlangıçta medya desteğini de arkasına almıştı. Bu olumlu hava AKP’nin 2004 yılındaki ikinci seçim zaferinin ardından bozulmaya başlamıştır. Bir grup siyasi elitin bazı medya sahipleri ile birlikte AKP iktidarına son verme girişimleri medya ile iktidar arasında geri dönüşü olmayan bir gerilime neden olmuştur. Bu çatışma, Doğan Grubu’nun hükümetin reform paketine muhalefetiyle dikkat çekici hale gelmiştir. Üniversitelerde başörtüsü yasağının kaldırılması için yapılan Anayasa değişikliği sırasında 10 Şubat 2008'de Hürriyet gazetesinin tasarıya onay veren milletvekillerini kastederek attığ “411 el kaosa kalktı" manşeti bu çatışmanın en önemli noktalarından biridir. Ülkenin en etkili gazetesi olan Hürriyet, o dönemde laikliğin korunması adına emekli generallerin ve kuvvet komutanlarının başında bulunduğu dernekler tarafından gerçekleştirilen "Cumhuriyet mitingleri” için kamuoyu oluşturulmasında önemli bir işlev üstlenmiştir. ${ }^{26}$ AKP’nin bu medya muhalefetine cevabı, ikili bir strateji izleyerek olmuştur. Bir taraftan ağır vergi cezaları uygulayarak Doğan Grubu'nu küçülmeye zorlamış $^{27}$, diğer taraftan ana akım medyayı yeniden şekillendirmeye başlamıştır.

Bu dönemde Doğan Grubu, iktidar baskısıyla Star TV, Milliyet ve Vatan gazetelerini satmak durumunda kalmıştır. 2011 yılında yürürlüğe giren 6112 sayılı kanunla medya kuruluşlarının pazar paylarının \%30 ile sınırlama kuralı getirilmiştir. Buna bağlı olarak Doğan Grubu elindeki Star TV'yi Doğuş Grubu'na, Milliyet ve Vatan Gazetelerini de Demirören ve Karacan ortaklığına satmıştır. 2012 Şubat ayında bu gazetelerin kontrolü tamamen Demirören Grubu'na geçmiştir. ${ }^{28}$

Aynı dönemde, bu krizden yara almadan çıkan bir başka kuruluş ise Doğuş Grubu’dur. 2001 öncesi yalnızca dergi sektöründe faaliyet gösteren Grup, kriz sonrasında Çağlar Grubu'ndan NTV’yi, küçük bir işletmeciden Kanal E’yi satın alarak, haber kanalı NTV’yi ve finans ve eğlence kanalı CNBC-E’yi kurmuştur. Doğuş Grubu, medya yayın anlayışı bakımından iktidarla uyumlu halini günümüze kadar özenle sürdür-

25 Sönmez, s. 98-99.

26 Yusuf Özkır, “Türkiye’nin Yakın Siyasi Tarihi ve Hürriyet Gazetesinde Laiklik Haberleri: Aydın Doğan Dönemi”, Iğdır Üniversitesi Sosyal Bilimler Dergisi, 4, (2013), s. 87.

27 CNN Türk, "Doğan Holding'e Rekor Ceza”, 18 Şubat 2009. http://www.cnnturk.com/2009/ekonomi/ sirketler/02/18/dogan.holdinge.rekor.ceza/514295.0. Erişim: 25.09.2015.

28 Ceren Sözeri, “Dönüşen Medya Değişmeyen Sorunlar”, haz., Esra Arsan ve Savaş Çoban, Medya ve İktidar, (İstanbul: Evrensel Basım Yayın, 2014), s.74. 
müştür. Bu iktidarla uyum içerisindeki yayın politikası özellikle Gezi Parkı Olayları ${ }^{29}$ sırasında toplumun önemli bir kesimi tarafından eleştirilmiştir.

AKP iktidarı, yukarıda sıralanan süreçler sonrasında TMSF yoluyla medya şirketlerine el koyup daha sonra iktidara yakın bir kişi ya da firmaya satmayı adeta sıradan bir işlem haline getirmiştir. AKP iktidarının medya alanında TMSF marifetiyle yeni bir medya oluşturma sürecinin Star Gazetesi’nin Kıbrıslı işadamı Ali Özmen Safa’ya satışıyla başladığı söylenebilir. ${ }^{30}$ Daha sonraki dönemlerde AKP’nin oy oranlarının artmasıyla doğru orantılı olarak bahse konu yöntemle medyadaki yapılanma devam etmiştir.

2007 yılında ülkenin ikinci büyük medya grubu AKP’ye yakın bir sermaye grubu tarafından devlet bankalarından sağlanan kredilerle satın alınmıştır. ${ }^{31}$

Son olarak TMSF Mayıs 2013'te borçları sebebiyle içinde Show TV, Akşam Gazetesi ve Digitürk Platformu'nun da bulunduğu Çukurova Grubuna kademeli olarak el koydu. ${ }^{32}$ Ayrıca yine aynı grubun içinde olan ve New York borsasında işlem gören Türkiye'nin en büyük GSM şirketlerinden Türkcelle de uzanacağının sinyalini verdi. ${ }^{33}$ Sonrasında Show TV ihalesiz bir şekilde Ciner Grubuna satıldı. Bunun üzerine İdare mahkemesinin aldığı bir kararla satış iptal edildi ve TMSF Show TV’yi tekrar devraldı. ${ }^{34}$ Yine aynı grubun içinde var olan 360 TV, Akşam ve Güneş gazetelerinin de içinde olduğu Akşam Yayın Grubu yine TMSF yoluyla el değiştirmiş olan Star Medya Grubu'nun da sahipliğini yürütmüş Ethem Sancaka ${ }^{35}$ devredilmiştir. Bu yayın grubu daha sonra Türkmedya Yayın Grubu olarak faaliyetlerine devam etmiştir.

$\mathrm{Bu}$ dönemde medyadaki ağırlık merkezi, muhalif medyadan iktidar taraftarı medyaya doğru kaymıştır. Bazı analistlerin değerlendirmelerine göre, AKP’nin iktidara gelmesi Türkiye'deki medya düzeninde bir dönüm noktasıdır. Medyadaki bu değişim ile iktidarın dönemsel yönetme üslubu arasında güçlü bir korelasyon bulunmaktadır. Örneğin, Gülseren Adaklı'ya göre:

29 Detaylı bilgi için bkz: Vikipedi, “Gezi Parkı protestoları”, https://tr.wikipedia.org/wiki/Gezi_Parkı_protestoları. Erişim: 17.04.2015.

30 Ek bilgi için bkz: Ekonomi Gazete, "Ali Özmen Safa cin gibi”, 6 Mart 2007. http://www.ekonomigazete.com/ haberdetay/4581-ali-ozmen-safa,-cin-gibi.html. Erişim 20. 09.2015.

31 Ek bilgi: Bahse konu medya grubunu alan Çalık Holdingin üst düzey yöneticiliğini uzun süre mevcut cumhurbaşkanın damadı Berat Albayrak yürütmüştür. Berat Albayrak 2015 genel seçimlerinde milletvekili seçilmiş; halen bu medya grubunun üst yönetiminde Berat Albayrak’ın kardeşi Serhat Albayrak bulunmaktadır. Aynı zamanda Basın İlan Kurumu (BİK) Genel kurul Üyesi olan Serhat Albayrak’n BİK'in web sitesindeki özgeçmişi için bkz: http://www.bik.gov.tr/dr-serhat-albayrak-biyografisi-50. Erişim: 20.09.2015.

32 Hürriyet Gazetesi, "Show TV ve BMC’ye TMSF el koydu”, 18 Mayıs 2013. http://www.hurriyet.com.tr/ ekonomi/23312091.asp. Erișim: 28.09.2015.

33 Milliyet Gazetesi, “TMSF Digiturk' el koydu 'Turkcell'e gideriz’ dedi”, 24 Mayıs 2013. http://www.milliyet.com. tr/tmsf-digiturk-e-el-koydu/ekonomi/detay/1713770/default.htm. Erişim: 28.09.2015.

34 Hürriyet Gazetesi, “TMSF sattı̆̆ Show TV’ye el koydu”, 31 Mayıs 2014. http://www.hurriyet.com.tr/ ekonomi/26521421.asp. Erişim: 28.09.2015.

35 Ek bilgi: Star Medya Grubu yönetim kurulu başkanlığını halen (28.09.2015 itibariyle) Ethem Sancak’ın yeğeni Murat Sancak yürütmektedir. Şu an için Türkiye’nin en büyük medya gücüne sahip kişilerinden Ethem Sancak, aynı zamanda AKP üyesi ve ombudsmanı olduğunu kendisi ifade etmiştir. Bkz: http://t24.com.tr/haber/ ethem-sancak-aydin-dogan-iktidarla-girdigi-catismalarda-aracilik-etmemi-istedi-kabul-ettim,307596. Erişim: 28.09.2015. 
Türk medyasının geleneksel unsurlarını karşısına almak konusunda 'cesur' davranan Recep Erdoğan'ın bu cesaretinde belirli bir medya stratejisinin izlerini görmek zor değildir. Dünyada olduğu gibi, Türkiye siyasetinde de özellikle haber medyasının yönlendiriciliğinin artması, Erdoğan’a bu kurumu doğrudan siyaset aracı olarak kullanmak konusunda, her seferinde birlikte kameralara samimi pozlar verdiği Berlusconi ya da Murdoch örneklerinden devşirilmiş, 'çalışan' formüller sunulmuştur. ${ }^{36}$

Haberciliğin en temel ilkesi "halkın doğru bilgilendirilmesi" iktidar güdümündeki medya organlarında geri planda kalmaktadır; bu bakımdan medyanın etkinliği zayıflamaktadır. Oto sansüre uğrayan haberlerle, halkın yeterince bilgilenmesi önlenmekte ve halkın tercihleri bu medya yapısında manipülasyonlara açık hale gelmektedir. Ragıp Duran’a göre, eskiden apoletli olan, ordudan talimat alan medya artık yeşil olmuş ve aynı ast-üst ilişkisi içinde iktidardan talimat alır hale gelmiştir. Duran, bu durumla ilgili sert eleştirisine örnek olarak Erdoğan’n Ekim 2011'de medya sahipleri ve yöneticileriyle yaptığı ve terörizm ve şiddet olaylarının haberleştirilmesinde duyarlı olunmasını talep ettiği basına kapalı toplantıyı göstermiştir. ${ }^{37}$ Bu toplantıdan hemen sonra ülkenin beş büyük haber ajansı ortak bir bildiriyle "yetkili mercilerin yasaklarına uyacaklarını" açıklamışlardır. Yapılan bu açıklamaya ülke içinde neredeyse basın özgürlüğü bağlamında hiç itiraz olmamıştır. Bu noktada Türkiyede basın özgürlüğü bakımından sivil toplum kuruluşlarının yetersizliği ayrıca incelemeye değer görülmektedir. Bahse konu bildiriye karşı yurt dışından Sınır Tanımayan Gazeteciler (RSF) tarafından, "hükümet ve dönemin medya sahiplerine yönelik en hassas konuların işlenmesi hususunda yetkili makamların medyaya direktif verdikleri çağın Türkiye'de geride kaldığını düşünüyorduk"38 şeklinde bir açıklamayla sert bir tepki gelmiştir.

Demokratik yönetimin olmazsa olmazlarından sayılan medya, sağlıklı işlemediğinde, halk, iktidarın baskısı ya da mali endişelerle yayıncılık yapan medya ile yüz yüze gelmekte ve alternatif bilgi kaynaklarından yoksun kalmaktadır. Sonuçta, kendisini temsil edecek olanları bu yetersiz ya da kirli bilgi ortamında belirlemeye çalışmaktadır; bu ise mevcut sistemin fasit bir daire içerisinde sürüp gitmesine hizmet etmektedir.

TMSF-medya ilişkisini ve bugünkü medya düzeninin oluşmasında TMSF’nin oynadığı rolü değerlendirebilmek için son yıllarda TMSF yoluyla el değiştiren başlıca medya organlarını dikkate almak gerekir:

- Televizyon Kanalları: Star TV, Show TV, ATV, Skytürk 360, Showmax,

36 Gülseren Adakl1, “2002-2008: Türk Medyasında AKP Etkisi”, AKP Kitabı: Bir Dönüşümün Bilançosu, der., İlhan Uzgel ve Bülent Duru (Ankara, Phoenix Yayınevi, 2013), s. 559-613.

37 Ragıp Duran, "Hakiydi Yeşil Oldu Egemen Medya”, Apoletli Medya, http://apoletlimedya.blogspot.com. Erişim: 01.11.2011.

38 Reporters without Borders, “Journalists under Pressure As Government Pursues Military Offensive Agasinst PKK” 7 Ağustos 2013. http://en.rsf.org/turkey-journalists-under-pressure-as-26-10-2011,41282.html. Erişim: 07.04.2015. 
TürkÇ TV, Kanal 1, ATV Avrupa, İzmir TV, Teleon, Kral TV, TV Star 2, Star Max, Kral Avrupa, HBB, Star 4, Dizi TV, Max Haber, Star 24, Yeşilçam TV, Metro TV, Fashion TV, Türkiye Nev TV, Futgol TV, Star 3, Star 5, Star 6, Star 7, Star 8, Star Spor, Star Movie, Test Joy TV, Performance Channel AS TV, Einstein TV, Galeri 1, Galeri 2, Kanal 6, Gala TV, Viva TV, Cine 5, Nickelodeon (Türkiye), Showmax, Supersport TV...

- Gazeteler: Sabah, Sabah Avrupa, Yeni Asır, Takvim, Fotomaç, Akşam, Güneş, Star Gazetesi.

- Radyo İstasyonları: Süper FM, Kral FM, Metro FM, Joy FM, Lokum FM, Joy Türk FM, Matrix FM, Rock FM, Radyo Alaturka, Ritmo Latino Radyo, Blue Radyo, King Radyo Gold, AlemFM...

- Diğer Basın Kuruluşları: Star Digital, Digi Fun Club, Star Televizyon Hizmetleri A.Ş, Star Medya Grubu, Park Medya Filmcilik, Medya Park Yayınc1lık, Ulusal Medya Haber Ajansı, Birikim Gazetecilik ve Matbaacılık Merkez Kağıt Torba Sanayi ve Ticaret A.Ş.

- Dergiler: Cosmopolitan, Cosmo Girl, Auto Motor Sporları, Sinema, Harper's Bazaat, Esquire, Forbes, Sofra, Bebeğim, House Beautiful, Global Enerji, Transport, Touch Star Dergi İstanbul, China Today, Para, Otohaber, Şamdan, Aktüel. ${ }^{39}$

Yukarıda sayılan medya şirketlerine TMSF, mevzuattan kaynaklanan yetkisi dâhilinde el koymuş; birçoğu belli bir süre "TMSF şartlarında faaliyette bulunmuş, ihale yoluyla daha sonra el değiştirmiştir. Bu şirketler devralındıktan sonra, uzun süre TMSF tarafından atanan, iktidara yakın kişiler tarafından yönetilmiş olması dikkat çekicidir. ${ }^{40}$ Yayın organlarının yaşadığı bu ara dönemde, yayın politikaları da kamu adına muhalefetten uzak ve iktidarla oldukça uyumlu bir şekilde sürmüştür. Bu medya gruplarının TMSF tarafından el konulduğu dönemlerde, sahibinin dolaylı da olsa devlet olması, yapılan gazetecilik çalışmalarını ayrıca tartışmalı hale getirmektedir. TMSF tarafından yeni sahiplerine satılan ve sürdürdükleri yayın politikası sonucu ortaya çıkan tiraj ve raitingle ayakta kalmaları imkansız olan bu medya organları, büyük ölçüde kamu reklamları ile varlıklarını sürdürmektedirler. ${ }^{41}$

39 Raşit Kaya, İktidar Yumağı (İstanbul: İmge Yayınları 2009), s. 247-271.

40 Konu ile ilgili bir milletvekilinin soru önergesine karşıllk dönemin TMSF Başkanının verdiği cevap için bkz. http://www2.tbmm.gov.tr/d22/7/7-19929c.pdf. Erişim: 19.09.2015. Ayrıca ilgili konuda ayrıca bkz., TMSF yoluyla el değiştiren bir grubun yayın organı olan TV24'te üst düzey yöneticilik de yapan Mustafa Hoş'un kaleme aldı ̆̆ı Abluka başlıklı kitabı. İstanbul: Destek Yayınları 2014, s.281-283. Ayrıca bkz: http://www.cumhuriyet. com.tr/haber/siyaset/79883/CHP_den_TMSF_hakkinda_suc_duyurusu.html. Erişim: 19.09.2015. http://www. son-dakika.org/gundem/mehmet-ali-gokce-kimdir-hayati-biyografisi.html. Erişim: 25.09.2015. Konuyla ilgili TBMM'deki tartışmalar için ayrıca bkz: https://www.tbmm.gov.tr/develop/owa/ab_komisyonu_web.birlesim_ baslangic_ab2?P4=22051\&P5=B\&page1=26\&page2=26. Erişim: 23.09.2015.

41 The Nielsen Company'nin AdEx raporunun özetlendiği haber için bkz: http://www.cumhuriyet.com.tr/haber/ turkiye/204567/Devlet_yandas_medyayi_reklamla_zengin_etti.html. Erişim: 07.09.2015. 


\section{Sonuç}

İktidarların basını kontrol etme ve kendi güdümlerinde basın oluşturma çabaları her devirde görülür. Amerika Birleşik devletleri Başkanlarından Thomas Jefferson 'gazetesiz bir hükümetimiz mi, yoksa hükümetsiz gazetelerimiz mi olsun sorusuna cevap vermek bana düşse, bir an bile tereddüt etmeden ikinciyi seçerdim' der. ${ }^{42}$ Zira bir demokrasinin sağlıklı şekilde işlemesinin en önemli şartlarından biri özgür basının varlığıdır. Haliyle, sermaye-medya ve medya-siyaset ilişkilerinin hukukun üstünlüğü ilkesine göre şekillendiği, şeffaflaştığı ve denetlenebildiği yerde "basın özgürlügüunden" bahsedilebilir. Diğer türlü, basının kamu adına denetleme görevini yerine getiremediği toplumlarda, basın özgürlüğü ve demokrasi kuru bir iddiadan ibaret kalır.

Türkiye'de iktidarlar sık sık kamu gücünü ve yetkilerini medyayı yönlendirmek, s1nırlandırmak için kullanmışlardır. TMSF, BİK, BEK, RTÜK ve Anadolu Ajansı yoluyla medya bir şekilde düzenlenmekte, biçimlendirilmektedir. Kamu yararı ilkesi çerçevesinde mevduat sahiplerinin tasarruflarını korumak amacıyla kurulmuş olan TMSF'nin medya ile ilişkisi hayli sorunludur. Halkın bankalardaki mevduatını koruma amacıyla imtiyazlarla donatılmış bir kurum olan TMSF’nin, medya kuruluşlarına kolayca el koyabilmesi paradoksal bir sorundur. Zira bir kamu kurumu olan TMSF'nin faaliyetlerini de halk adına denetleyebilmesi gereken medya kuruluşlarına "halk adına" el konularak toplumun en temel insan haklarından olan "doğru haber alabilme hakkı” engellenmektedir.

TMSF Türkiyedeki medya gruplarının el değiştirmesinde rol oynayarak mevcut medya düzeninin oluşumunda etkili olmaktadır. TMSF yoluyla yayın organlarının el değiştirmesi iktidara iki yönlü avantaj sağlamaktadır: Birincisi el konulan yayın organları genel itibariyle hükümete muhalif yayın yapan medya organları olduğundan bu yolla susturulmaktadırlar. İkincisi ise, iktidarla ilişkili işadamları zahmetsiz bir şekilde önemli yayın organlarını elde etmekte ve iktidarın hizmetine sunmaktadırlar. Böylece iktidar gündem belirleme ve kamuoyu algısını yönetmede geniş bir medya gücüne sahip olurken; bu yolla yönetime dair önemli sorunlar da kamuoyu gündeminden uzak tutulmaktadır.

Gazeteciliğin ruhunda olması gereken "kamu adına muhalif duruş” Türkiye’de hayli zayıflamıştır. Yeni oluşan medya yapısında, devlet gücünün de etkisiyle iktidara yakın yayın politikasını benimsemiş medyanın dengesiz bir ağırlığı bulunmaktadır. Bu medya gücü vasıtasıyla toplum yoğun bir şekilde iktidar yanlısı enformasyona maruz kalmaktadır. Bu atmosferde, tarafsız ya da muhalif yayın yapan medya organlarının kendiliğinden oluşturduğu oto sansür etkisi de yayınlarda kendini hissettirmektedir. Medyanın genel yapısında yaşanan değişiklikler, AİHM’nin ifade özgürlüğü konusunda Türkiye ile ilgili aldığı aleyhte kararlar ve basın özgürlüğü sıralamasında yaşanan irtifa kaybı sorunu göz önüne serer niteliktedir.

42 George Tucker, The Life of Thomas Jefferson (Phileadelphia: Carey, Lea \& Blanchard, 1837), s. 1, 254. 


\section{Kaynakça}

Adaklı, Gülseren. "2002-2008: Türk Medyasında AKP Etkisi”. AKP Kitabı: Bir Dönüşümün Bilançosu, der., İlhan Uzgel ve Bülent Duru, Ankara: Phoenix Yayınevi, 2013, 559-613.

AİHM. "Süzer ve Eksen Holding v. Türkiye Kararı". Karar No: 6334/05. Tarih: 23.10.2012.

Akın, Doğan. “Medya Patronları, Bırakın Biraz da Başkaları Ölsün!”, T24, Erişim: 10.07.2012. http://t24.com.tr/yazi/medya-patronlari-birakin-biraz-dabaskalari- olsun.

Ayzit, Müge. "Dünyada ve Türkiyede Mevduat Sigorta Sistemi Uygulamaları". Uzmanlık Tezi, TCMB, 2004.

Balaban, Ercan ve Hüseyin Çilli. "A Proposal For A Deposit Insurance System in Turkey". The ISE Review. 1/2, (1997): 1-22.

Berkan, İsmet. “Postmodern darbe mi?”. Radikal, 26 Nisan 2003, Erişim: 01.02.2015. http://www.radikal.com.tr/yazarlar/ismet_berkan/postmodern_darbe_mi667916.

Basın İlan Kurumu. "Serhat Albayrak Biyografisi”, http://www.bik.gov.tr/dr-serhatalbayrak-biyografisi-50. Erişim: 20.09.2015.

BBC Türkçe. “Türkiye basın özgürlüğünde 180 ülke arasında 154. sırada”. http://www.bbc.com/turkce/haberler/2014/02/140212_rsf_turkiye, Erişim: 15.04.2015.

Christensen, Clayton. "Concentration of ownership, The Fall of Unions and Government Legislation”. Global Media and Communication. 3/2 (2007): 179199.

CNN Türk. “Doğan Holding'e Rekor Ceza”. http://www.cnnturk.com/2009/ekonomi/ sirketler/02/18/dogan.holdinge.rekor.ceza/514295.0, Erişim: 25.09.2015.

Cumhuriyet Gazetesi. "CHP'den TMSF hakkında suç duyurusu”. http://www. cumhuriyet.com.tr/haber/siyaset/79883/CHP_den_TMSF_hakkinda_suc_ duyurusu.html. Erişim: 19.09.2015.

Cumhuriyet Gazetesi. "Devlet yandaş medyayı reklamla zengin etti". http://www. cumhuriyet.com.tr/haber/turkiye/204567/Devlet_yandas_medyayi_reklamla_ zengin_etti.html. Erişim: 07.09.2015.

Duran, Ragıp. "Hakiydi Yeşil Oldu Egemen Medya”. Apoletli Medya, 1 Kasım. http://apoletlimedya.blogspot. com. Erişim: 01.11.2011.

Ekonomigazete.com. "Ali Özmen Safa Cin Gibi”. http://www.ekonomigazete.com/ haberdetay/4581-ali-ozmen-safa,-cin-gibi.html. Erişim: 20. 09.2015.

Ertem, Cemil. “Medya, Finans ve Bir Buzkıran olarak TMSF”. Taraf. 10.06.2008.

Flannery, Mark J. “Deposit Insurance”. The New Palgrave Dictionary Of Money and Finance. London: The Macmillan Press, 1994.

Garcia, Gillian. "Deposit Insurance and Crisis Management”. IMF Working Paper. 99/54 (1999): 1-49. 
Gençler, Ayhan. "2001 Ekonomik Krizinin Bankacılık Sektöründeki İstihdama Etkisi”, Sosyal Siyaset Konferansları, 50 (2005): 351-365.

Hoş, Mustafa. Abluka. İstanbul: Destek Yayınları, 2014.

Hürriyet Gazetesi. “Show TV ve BMC’ye TMSF El Koydu”. http://www.hurriyet.com. tr/ekonomi/23312091.asp. Erişim: 28.09.2015.

Hürriyet Gazetesi. “TMSF Sattı̆̆1 Show TV’ye El Koydu.” http://www.hurriyet.com. tr/ekonomi/26521421.asp. Erişim: 28.09.2015.

Kaya, Raşit. İktidar Yumă̆ı. İstanbul: İmge Yayınları, 2009.

Keane, John. Medya ve Demokrasi. Çev., Haluk Şahin. İstanbul: Ayrıntı Yayınları, 2013.

Küçüközmen, Coşkun. "Mevduat Sigortası”. İşletme İktisat ve Finans Dergisi. 11/22 (1996): s. 45-53.

Madison, James. The Writings of James Madison. Ed., Gaillard Hunt, Chicago: University of Chicago Press, 2000.

Milliyet Gazetesi. “TMSF Digiturk'e El Koydu 'Turkcell’e gideriz’ dedi”. http://www. milliyet.com.tr/tmsf-digiturk-e-el-koydu/ekonomi/detay/1713770/default.htm. Erişim: 28.09.2015.

Özkır, Yusuf. “Türkiye’nin Yakın Siyasi Tarihi ve Hürriyet Gazetesinde Laiklik Haberleri: AydınDoğan Dönemi”. Iğdır Üniversitesi Sosyal Bilimler Dergisi, 4 (2013): 69-94.

Özsever, Atilla. Tekelci Medya Örgütsüz Gazeteci. Ankara: İmge Yayınevi, 2004.

Reporters Without Borders. "Journalists under Pressure As Government Pursues Military Offensive Agasinst PKK" 7 Ağustos 2013. http://en.rsf.org/turkeyjournalists-under-pressure-as-26-10-2011,41282.html. Erişim: 07.04.2015.

Resmi Gazete, Bankacılı Kanunu. 2005. http://www.resmigazete.gov.tr/ eskiler/2005/11/20051101M1-1.htm. Erişim: 10.02.2015.

Saran, Ceren. "Medyada Mülkiyet İlişkileri AKP Döneminde Medya Sahipliğinde Yaşanan Değişimler". I. Uluslararası İletişim Bilimi ve Medya Araştırmaları Kongresi Türkiye Bildiri Kitabı - I, Kocaeli: Volga Yayıncılık, 2014, 355-373.

Son Dakika Haber Sitesi. "Mehmet Ali Gökçe kimdir, hayatı, biyografisi". http:// www.son-dakika.org/gundem/mehmet-ali-gokce-kimdir-hayati-biyografisi. html. Erişim: 25.09.2015.

Sözeri, Ceren. “Dönüşen Medya Değişmeyen Sorunlar”. Haz., Esra Arsan ve Savaş Çoban, Medya ve İktidar, İstanbul: Evrensel Basım Yayın, 2014.

Sözeri, Ceren ve Zeynep Güney. Türkiye’de Medyanın Ekonomi Politiği: Sektör Analizi. İstanbul: TESEV Yayınları, 2011.

Sönmez, Mustafa, Dünden Bugüne Türkiye'de Medyanın Ekonomi Politiği. Haz., Esra Arsan ve Savaş Çoban, Medya ve İktidar, İstanbul: Evrensel Basım Yayın, 2014.

Sözeri, Ceren. Türkiye'de Medya-İktidar İlişkileri. İstanbul: İstanbul Enstitüsü Yayınları, 2015.

TBMM 28 Şubat Araştırma Komisyonu. “16.10.2012 tarihli oturum tutanağı”, https://www.tbmm.gov.tr/arastirma_komisyonlari/darbe_muhtira/docs/ 
tutanak_son/28_subat_alt_komisyonu/28_subat_alt_komisyonu/16.10.2012/ Ahmet\%20Ert\%C3\%BCrk-16.10.2012.pdf. Erişim: 07.04.2015.

TBMM. "7/19929-28871 sayll Yazılı Soru Önergesine Dair Tasarruf Mevduatı Sigorta Fonu Başkanlığı’nın Cevabı", http://www2.tbmm.gov.tr/d22/7/7-19929c. pdf. Erişim: 19.09.2015.

TBMM Genel Kurul Tutanağı, 24. Dönem 4. Yasama Yill, 42. Birleşim 02/Ocak/2014. https://www.tbmm.gov.tr/develop/owa/ab_komisyonu_web.birlesim_ baslangic_ab2?P4=22051\&P5=B\&page1=26\&page2=26. Erişim: 23.09.2015.

TMSF. “TSMF Tarihçesi”. http://www.tmsf.org.tr/default.html. Erişim: 07.04.2015.

TMSF. “TMSF İdari ve Hukuki Yapı”. http://www.tmsf.org.tr/idari.hukuki.tr. Erişim: 07.04.2015.

Tucker, George. The Life of Thomas Jefferson. Phileadelphia: Carey, Lea \& Blanchard, 1837.

T24 Haber Sitesi. "Ethem Sancak: Aydın Doğan, iktidarla girdiği çatışmalarda aracilık etmemi istedi, kabul ettim". http://t24.com.tr/haber/ethem-sancakaydin-dogan-iktidarla-girdigi-catismalarda-aracilik-etmemi-istedi-kabulettim,307596. Erişim: 28.09.2015.

Vikipedi. “Gezi Parkı protestoları”. 2015. https://tr.wikipedia.org/wiki/Gezi_Park1_ protestoları. Erişim: 17.04.2015.

Yüksel, Erkan. "28 Şubatın anlamı...". Özgür Gazeteciler Platformu, 28 Şubat 2011. http://dorduncukuvvet.com/erkanyuksel/3093-28-subatin-anlami.html. Erişim: 01.03.2015. 


\title{
The Role of Savings Deposit Insurance Fund in the Formation of New Media Order in Turkey
}

BORA ERDEM

\begin{abstract}
Significant changes have been witnessed in Turkey especially after 1990 in the fields of media and capital. After the transition to free markets which began in 1980s new actor took place in economy. Political and economic crisis which were experienced in the same period led to the bankruptcy of holdings consisting of banks and media companies. Saving Deposit Insurance Fund (TMSF) which was founded in order to protect the depositors of the bankrupt banks took over the companies of the said companies. Thus, in one way, critical media companies went under the control of the governing party. These companies which were managed by TMSF for a certain period were sold with private placement to the businessmen close to the governing party with tender which were not subject to public tenders act. The fact that these opposition media groups which used to air very back-breaking broadcasts against the government suddenly became very supportive of the government (after this process in the centre of which TMSF stood) created the perception that a "partisan media structure" was designed in favour of the government. It is sure that TMSF institutionally is not the only element for creating this result. As will be seen in the end of the paper, several government agencies and instruments played active role in obtaining this result. However, due to space limitations, this paper will deal with foundation and functions of TMSF, the relations between media and TMSF and some media companies of which ownership structure was changed in this process with the intervention of TMSF.
\end{abstract}

Keywords: TMSF, Media, Democracy, Media economy. 